\title{
Commercialization and Mission Drift - A Cross Country Evidence on Transformation of Microfinance Industry
}

\author{
Afsheen Abrar and Attiya Y. Javaid
}

\begin{abstract}
The present study examine the most important issue faced by microfinance institutions around the world in this present era that is the commercialization trend and drifting size. This study will analyze whether the commercialization from their primary function of serving poor class of the society to moving towards better off customer in order to satisfy their urge of financial benefits. This study is using average loan size as proxy of mission drift with operational self sufficiency as profit measure, productivity as cost measure and repayment risk as independent variables in the study .The study also accommodate age, size as control variables .Data has been taken from all the six regions of the world from $\mathbf{7 2}$ countries for the years 2003 to 2009. The econometric evidence using random effect estimation technique reveals that profitability and risk are positively related with average loan size where as cost is inverse relation with size of loan. The impact of age and size varies from region to region.
\end{abstract}

Index Terms-MFIs, AVGLS, OSS, PROD, REM.

\section{INTRODUCTION}

Microfinance moment is started in e during 1970, since from than this industry very successful among developing countries all over the world. The main promise of this industry is to provide poor class of the society low cost financial service at the same time in order to be remain sustainable its necessary for them to earn reasonable profits. But from the early years of 2000, it has been observed all over the world that there is a there is an inclinations toward profit making that is really an alarming sine for the governments regulator and donors. This is really a concern in this study to know about this mystery which is known as mission drift.

Banco Sol, from Bolivia was the first MFI which undergo the evolution into a commercial bank in 1992.After that there starts a movement in micro finance industry to change from not- for-profit organization to commercialized institutions provide loans to public on high interest rates as to regular banks operating in the country. So today it is an urgent need of time to put attention to this emerging phenomenon because it has severe implications for the poor community because they are the one who provide reason for existence of microfinance products and institutions.

This topic is very crucial and significant because very limited empirical research is done on the consequence of commercialization in microfinance industry. The "depth of outreach" in microfinance industry is denoted as the ability of

Manuscript received August 19, 2013; revised October 20, 2013.

Afsheen Abrar is with the Shaheed Zulfikar Ali Bhutto Institute of Science and Technology, Islamabad, Pakistan (e-mail: afsheenabrar@gmail.com).
MFI to reach to the poorest of the society .This study has taken it as dependent variable and denoted by average loan size. This study will analyze whether the commercialization of the microfinance industry has consequences on the depth of outreach on a worldwide scale.

\section{A. Rationale of the Study}

It is a widespread phenomenon that MFIs are departing from their actual mission of poverty alleviation and focusing more on their sustainability side. So it's a matter of interest for the donors and borrowers to know the various indicators those drifting MFIs from their social objective of poverty alleviation. Therefore the study is aiming to investigate how MFIs can maintain a tradeoff between sustainability and social mission in order to away from commercialization.

\section{B. Problem Statement}

As micro finance industry is growing over time, MFIs are focusing more on their financial side. This phenomenon results as the occurrence of mission drift (commercialization) in microfinance industry.

\section{Objectives of the Study}

Following objectives are intended to achieve from the study

1) To examine various indicators that lead to mission drift in microfinance industry.

2) To explore the implication of sustainability-driven scaling up activities in microfinance that lead to mission drift concern.

3) To analyze whether the commercialization of the microfinance market has consequences for the depth of outreach on a worldwide scale.

\section{LITERATURE REVIEW}

The issue that microfinance institutions are driven by mission to reach the poor is affected by commercialization is not widely researched. In this section important studies which are relevant to this issue are reviewed.

Christen \& Drake (2002) analyzes that commercialization and mission drift occurs in the Latin American market for microfinance, by using data of more than 200 MFI's which are active in this region]. According to Christen, who was one of the first to address the topic of 'commercialization' in microfinance, a commercial approach constitutes of three main principles, which are profitability, competition and regulation. MFI's in Latin America belong to the most profitable MFI's worldwide. The average Operational Self Sufficiency of Latin American was 1.4 percent, while the average return of all the institutions in the world together was 
4.5 percent in the same period (1996-1999) [1].

One of another main reason given by Rosenberg, Gonzalez \& Narain (2009), is the increasing number of regulated microfinance institutions as compared to non-regulated MFIs as stated .In Latin America Regulated MFI's consist of three types. In which the on the top are those financial Non Governmental Organizations which are converted into accredited microfinance institutions and requirements for doing operations as the commercial banks or financial institutions have for their operations. At 2nd position there are those MFIs which are considered as specially accredited institutions and consist of non baking financial intermediaries and credit unions. These MFIs are accredited under a special law instead of the law for general banking procedure. The third and largest in Latin America case those finance companies and conventional banks. Therefore in Latin America now regular commercial institutions have started operations in the microfinance industry and this is a main reason of growing competition among Latin Americans institutions [2]. The same result is given by another study conducted by Copestake (2007) [3].

According Pollinger,Outhwaite\&Guzman (2007) the main consequences of commercialization are that it micro finance institutions to target richer group of the society as opposed to poor class. Therefore the poorer customers might be left behind as consequence of this trend. He provides that regulated micro finance institutions on average lend loans of large denominations approximately 47.2 percent of GDP per capital. A consequence of a commercial approach could be that it drives institutions to focus on richer target groups. So due to commercialization, poorer clients might be left behind. Christen shows that regulated MFI's on average provide larger loans 47.2 percent of GDP per capita or $\$ 804$ as compared to unregulated MFIs who provide 23.6 percent of GDP per capita or $\$ 322$.So this thing provides signal that American MFIs have high mission drift scenarios[4].

Conversely, according to Gonzalez (2008) it is not necessary that large amount of loans always is due to commercialization aspect. There could be multiple reasons of this strategy. For instance most of the Latin American microfinance institutions want to reduce poverty by reaching to the poorest person in the society. Rather they focus on the development of small scale businesses that can generate employment. Another case of increase in average amount of loan can be that initially the microfinance institute provides loan in small sizes to borrowers and when they become establish they start taking higher amounts of loans from the MFIs. And they allow them higher loans if their payment patterns are regular and default free [5].

Ditcher and Harper (2007) conduct a pooled OLS estimations by using data of 28 MFIs from Latin America in order to counter check the results of Christens\& Drake (2002).they used a number of conventional techniques for Average Loan Size as dependent variable Their results reconfirm the finding of Christen and Drake [6].

Olivares-Polance states (2005) in their study focus on other characteristics of microfinance institution like their type whether operating as NGO, age, breadth of outreach, competition, and gender and loan methodology. They found inverse relation between loan size indicating that mature an older microfinance give lower sizes loans to borrowers and vice versa. On the other side competition as measured by market share has coefficient that indicates that versa when loan size is small its shows low competition and vice versa and increase in competition leads to large size loan, as micro finance institute is searching money-spinning customers [7].

The study also focus on other characteristics of microfinance institution like their type whether operating as NGO, age, breadth of outreach, competition, and gender and loan methodology.

Another study conducted by Cull, Demirguc-Kunt \& Morduch (2007) using a data set from 49 countries on 124 micro finance institutions in order to investigate that is there any indication of tradeoff between sustainability and outreach to the poor. They examine this in order to check whether there are any sign of 'mission drift' or not. Their findings confirm the existence of "reverse mission drift' for individual lenders as their high margins are linked with increase outreach. After controlling the age and size, it indicates that older and larger individual lenders be likely to give loans to less poor customers. In their study village banking and group lending do not show considerable sign of mission drift [8].

Finally Hermes et al. (2009) showed the tradeoff between outreach and profitability in micro finance industry. By taking a sample of more than 1300 observations they found proof for an inverse relationship between outreach and profitability. Their findings confirm that micro finance institutions with a lower average loan size are less profitable as to those who have large loan sizes at their penal [9].

\section{THEORETICAL FRAMEWORK}

The study include three independent variables Operational Self Sufficiency(OSS) to measure profitability of MFIs, the reciprocal of productivity (PROD) measures operational cost and Portfolio at risk > 90days to measure the degree of risk. Mission drift is capture through Average loan size taken as dependent variable. The study uses Age and size as control variables. Whereas for dummy variables, the study has taken regulation, lending methodology, and type of MFI. The conceptual framework of this study is shown by the following models.

\section{Model 1:}

$\mathrm{AVGLSit}=\alpha+\beta_{1} \mathrm{OSS}_{\mathrm{it}}+\beta_{2} \mathrm{PROD}_{\mathrm{it}}+\beta_{3} \mathrm{RISK}_{\mathrm{it}}+$ $\beta 4 \mathrm{SIZE}_{\mathrm{it}}+\beta_{5} \mathrm{AGE}_{\mathrm{it}}+\varepsilon_{\mathrm{it}}$.

AVGLS = Average Loan Size

OSS $=$ Operational Self Sufficiency

PROD $=$ Proxy for operational cost

Size $=$ Log of Total assets

$\mathrm{AGE}=$ Years of Operating

In order to consider differences among regulation, status, across countries and years Dummy variables would be included in the study:

\section{Model 2:}

AVGLSit $=\alpha+\beta 1$ OSSit $+\beta 2$ PRODit $+\beta 3$ RISKit + $\beta 4$ SIZEit $+\beta 5$ AGEit $+\beta 6$ REGULATEDit $+\beta 7$ REGIONit + $\beta$ LEEGL STATUSit $+\beta$ 9Lending Methodologyit $+\varepsilon$ it.

\section{Hypothesis}

The following hypothesis will be tested to check the relationship between IVs and DV. 
$\mathrm{H} 1:$ There is a positive relationship between Average loan size and OSS.

$\mathrm{H} 2$ : There is a negative relationship between Average loan size and PROD.

H3: There is positive relation between Average loan size and repayment risk.

H4: There is positive relation between Average loan size and MFI Size.

H5: There is positive relation between Average loan size and MFI Age.

\section{DATA}

The data has been collected for 382 Micro finance institutions, located in 70 countries throughout the six regions of the world including Eastern Europe, Africa, South Asia, East Asia, Latin America, and Middle East. The data is on annual basis covering the period 2003 to 2009. So it is an unbalanced cross section-time series panel data with 2424 observations from Microfinance Information Exchange (Mix) which is an authentic source providing uniform data all over the world.

\section{A. Methodology}

The researchers have developed various models by following the study of Ditcher and Harper (2007). Therefore panel data estimation method is applied for estimating the relationship among variables using random effects model, and first difference.

\section{RESUlt AND DiSCUSSION}

A. Descriptive Statistics of Main Variables

\begin{tabular}{lrcr}
\hline \hline & \multicolumn{1}{c}{ Mean } & \multicolumn{1}{c}{ Median } & \multicolumn{1}{c}{ Std. Dev. } \\
\hline AVGLS & 0.51942 & 0.24485 & 0.84088 \\
PROD & $2.72 \mathrm{E}-05$ & $4.93 \mathrm{E}-07$ & 0.0012 \\
OSS & 1.00294 & 1.11265 & 0.59758 \\
RISK & 0.02148 & 0.005 & 0.0464 \\
\hline \hline
\end{tabular}

\section{B. Correlation Matrix}

\begin{tabular}{|c|c|c|c|c|}
\hline & AVGLS & PROD & OSS & RISK \\
\hline AVGLS & & & & \\
\hline PROD & -0.01268 & & & \\
\hline OSS & 0.164693 & -0.03298 & 1 & \\
\hline RISK & 0.130158 & -0.00983 & 0.04437 & 1 \\
\hline
\end{tabular}

There is no presence of multi-co linearity among the variables as shown by correlation matrix.

\section{Random Model with Control Variables}

\begin{tabular}{cllll}
\hline \hline Variable & \multicolumn{1}{c}{ Coefficien } & Std. Error & $t$-Statistic & Prob. \\
& $t$ & & & \\
\hline C & -1.3108 & 0.9547 & -1.373 & 0.1699 \\
PROD & 74940.9766 & 21217.9517 & -3.532 & 0.0004 \\
OSS & 0.2905 & 0.1116 & 2.6032 & 0.0093 \\
RISK & 7.2538 & 1.9607 & 3.6996 & 0.0002 \\
REG & 0.004 & 0.0537 & 0.074 & 0.941 \\
GENDER & 0.5542 & 0.2636 & 2.1024 & 0.0357 \\
NGO & 0.138 & 0.1581 & 0.8728 & 0.3829 \\
AGE & 0.0001 & 0.0003 & 0.276 & 0.7826 \\
SGL & -0.3172 & 0.1451 & -2.1866 & 0.0289 \\
REGUL & 1.4146 & 0.7974 & 1.7739 & 0.0763 \\
\hline \hline
\end{tabular}

The cost of operations has negative and significant effect on average size of loan capturing mission drift as the $t$ value is greater than 3 ,so proving that with the increase in loan size, the cost of operation decreases and vice versa. The profitability as measured through OSS has positive( $t$ value $>2$ ) and significant impact on average loan size showing that as microfinance institutions start given loans of large amounts, their profitability increases and thus singles out the existence of mission drift in microfinance industry. The estimations also reveals that risk has positive and significant effect on average loan size as the $t$ value is more than 3 , shown that as the size turns to increase the possibility of default on the part of borrower become also high. Whereas it's also proved that if MFIs are operating as NGO, it will give loans to poor borrowers in small denominations.

\section{Random Effect Model with $1^{\text {st }}$ Difference}

\begin{tabular}{lllll}
\hline \hline Variable & \multicolumn{1}{c}{ Coefficien } & Std. Error & t-Statistic & Prob. \\
\hline C & -0.861 & 0.552 & -1.561 & 0.119 \\
PROD & -0.002 & 0 & -8.522 & 0 \\
OSS & 0.206 & 0.103 & 2.01 & 0.045 \\
RISK & 3.637 & 1.404 & 2.591 & 0.01 \\
AGE & 0 & 0 & 0.038 & 0.97 \\
SIZE & 0.09 & 0.038 & 2.403 & 0.016 \\
GENDER & -0.117 & 0.142 & -0.822 & 0.411 \\
\hline \hline
\end{tabular}

The cost of operations has significant and negative impact on the size of loan, the proxy for mission drift as the t value is greater than 8 ,so proving that with the increase in loan size, the cost of operation decreases and vice versa. The profitability as measured through OSS has positive and significant as the $p$ value is less than .05. The estimations also reveals that risk has positive and significant effect on average loan size as the $t$ value is more than 2 and $p$ value is less than 0.05 , shown that as the size turns to increase the possibility of default on the part of borrower become also high. The gender and age have insignificant impact on loan. The size of microfinance institution has positive and significant impact on loan size. Large scale of operations, it will be better able to cater clients demanding high denominations. So Through estimations with 1st difference lag values it is confirm that over the period the tendency is same as to the prior period.

\section{E. Discussion}

The study has shown that microfinance industry is moving towards commercialization approach. The study hypothesized that profitability is positively related with average loan size. Our results evidence this hypothesis that as there is increase in average loan size it's a green signal that MFI is drifting from its main mission of poverty reduction as average loan size represent the depth outreach consideration this hypothesis is in line with the study of Mersland and Strom (2010), [10]. Another main factor is the operational cost of microfinance institutions as the loan size is small therefore the operational cost is greater as to the situation where the loan size is bigger. The third hypothesis is that when the average loan size increases the risk associated with the large amount is also increases .we have taken PAR $>90$ in 
our study as risk measure, that shows. The loan become overdue more than 90 days the rate of default is doubled as to the situation when it is overdue by 30 days or 90 days. Our study confirms this situation. As to size of microfinance institution, there are mix results means generally the size of MFI has in some case positive correlation with average loan size, the dependent variable of the study, as confirm by Common effect model and fixed effect model, but as to random effect model it is not so situation true as the model captures variation in terms of regions therefore in South Asia especially in Bangladesh. This is not so true but as to African and American region this can be true so on the basis of regional disparity in some cases our this hypothesis is accepted where as in some it is rejected. Same is the situation with age; normally in African and American regions older MFIs are involved in lending large amounts to clients because of profit motive where as in Eastern regions this situation is opposite. Therefore as to size and age the results are not completely final especially when we are covering all the six regions of the world.

As this is a cross country study involving regional disparity therefore the hausemen test suggests that random effect is the best model to rely upon. Overall results of this study confirm the findings of the few of earlier studies that have focused on mission drift and they agree on the philosophy given by Dr. Yunus (2011), the Founder of Grameen bank [11].

\section{CONCLUSION}

Over all the study captures all the main factors as independent and control variables. On the basis of penal data technique applied to the study, the results confirms the presence of commercialization in micro finance industry and giving support to Younas (2007) philosophy that microfinance industry is moving towards mission drift by ignoring their main social motive of Empowering poor class of the society and paying more attention on satisfying the financial objectives [12].

\section{REFERENCES}

[1] R. Christen and D. Drake, "Commercialization, the new reality of microfinance," The Commercialization of Microfinance, Balancing Business and Development, Kumarian Press by Stylus Publishing, pp. 2-22, 2002.

[2] R. Rosenberg, A. Gonzalez, and S. Narain, "The new Moneylenders: Are the poor being exploited," CGAP Occasional paper 15, Washington D.C., 2009.

[3] J. Copestake, "Mainstreaming microfinance: Social performance management or mission drift?" World Development Bank, vol. 35, no. 10, pp. 1721-1738, 2007.

[4] J. J. Pollinger, J. Outhwaite, and H. C. Guzman, "The question of sustainability for microfinance institutions," Journal of Small Business Management, vol. 45, no. 1, pp. 23-41, 2007.

[5] A. Gonzalez, "Efficiency drivers of microfinance institutions (MFIs): The case of operating expenses," MIX Discussion Paper No. 2. Washington D.C., 2008.

[6] T. W. Dichter and M. Harper, What's Wrong with Microfinance? 2007.

[7] F. Olivares-Polanco, "Commercializing microfinance and deepening outreach? Empirical evidence from Latin America," Journal of Microfinance, vol. 7, pp. 47-69, 2005.

[8] R. Cull, A. Demirguc-Kunt, and J. Morduch, "Financial performance and outreach: a global analysis of leading micro banks," The Economic Journal, vol. 117, pp. 107-133, 2007.

[9] N. Hermes, L. Robert, and M. Aljar, "Outreach and efficiency of microfinance institutions," Faculty of Economics and Business, University of Groningen, the Netherlands, 2009.

[10] R. Mersland and R. O. Strom, "Microfinance mission drift," RUME Working Papers Series, 2009-04, Marseille, IRD, pp. 28-36, 2010.

[11] M. Yunus. (2011). Sacrificing microcredit for mega profits. The New York Times. Editorial Desk. [Online]. Available: http://www.nytimes.com/ 2011/01/15/opinion/15yunus.html.

[12] M. Yunus, "Creating a world without poverty: Social business and the future of capitalism," The Electronic Journal of Sustainable Development, vol. 1, no. 1, Public Affairs, New York, 2007.

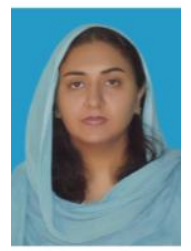

Afsheen Abrar obtained MBA degree from the Quaid-e-Azam University Islamabad, Pakistan. She is currently working as a lecturer in a regular capacity in National University of Modern Languages, Islamabad and pursuing her education as a Ph.D. research scholar of MS in Management Sciences at Shaheed Zulfikar Ali Bhutto Institution of Science and Technology, Islamabad, Pakistan. Her field of specialization is finance particularly microfinancing. She has also attended various professional and research trainings at domestic and international levels. Afsheen Abrar is the corresponding author and can be contacted at: afsheenabrar@gmail.com.

Dr Attiya .Y. Javaid is the co-author of this paper. She is currently serving as full professor and head of school of business and economics in Pakistan Institute of Development Economics, Islamabad, Pakistan. She has extensive research work on her credit in various areas of economics and finance. 